\title{
Android-Based Core Fiber Optic Management Information System Design In PT. Telkom Kebumen
}

\author{
Ari Waluyo ${ }^{1}$ Ega Latif Permana ${ }^{2}$ \\ ${ }^{1,2}$ Electronic Engineering Study Program, Politeknik Dharma Patria Kebumen \\ ari.hardware@yahoo.com,ega.yvc11@gmail.com
}

\begin{abstract}
The study aims to design the information system of fiber optic core management based on Android at PT.Telkom Kebumen. This study used qualitative method with a descriptive approach. Data collection techniques are carried out by observation and literature study that related to research. The software development method used waterfall. The problem of the research result are data processing of core management still using Ms. Excel so that the data received by technicians is not accurate because the data changes and data additions are slowly, and to looking for data is too difficult because the data that saved on Ms.Excel is too much. There are suggestions that submitted, designing a new information system that can help the job so that can be more effective and efficient. By utilizing the advanced android technology which owned by all technicians.
\end{abstract}

Keywords: Information System, Android, Core Mangement, Fiber Optic.

\section{Introduction}

Technology continues to develop from year to year very rapidly and increasingly, especially in the field of information both information from print and electronic media that presents information in the form of text, sound and images. For the community, they must be very clever to choose information sources that can be trusted and can be accounted for. Almost everyone needs information that is fast, practical, effective, and economical in presenting information.

In the era of smartphone technology, it is not only used as a medium for communication, but has been equipped with many other features. These features include: Camera, Mp3 Player, Games, and other applications that have more specific functions. A mobile phone that is equipped with an operating system like a computer, practical, highly capable is called a smartphone, its ability to install various applications to support the needs of its users.

PT. Telkom Kebumen whose basic is information and communication technology, smartphones are very important to support its development. PT. Telkom Kebumen itself, besides selling home telephone services, also sells internet and cable TV services, commonly called Indihome. The development of the digital era is now not only offices or companies that subscribe to Indihome, but also not a few home customers who subscribe to Indihome. Because the internet has now become a basic need for the people of Indonesia, especially Kebumen.

Many information systems at PT. Telkom Kebumen that use Android. Starting from the customer side, there is an application called MyIndihome that is useful for viewing packages that are owned, checking bills, adding services, and reporting complaints or disruptions that occur in the service. On the employee side there are also applications on staffing, such as applications for Absences, filing leave, salary slips, and so forth. Up to applications to help simplify the work of all android-based.

There are several engineering divisions at PT.Telkom Kebumen, such as installation or provisioning technicians, repair or assurance technicians and maintenance technicians. The jobdesc of the assurance technician himself is to 
troubleshoot and repair the Fiber Optic network which causes customers to not be able to enjoy indihome services. Like looking for fiber optic cable breaking points, fixing fiber optic distribution points and so on. In the fiber optic cable there is a core fiber called a core. There are many cores that function as data paths. One fiber optic cable contains 12 cores to 288 cores. So it needs management for the distribution of these cores so that they are structured and easy to troubleshoot when fibercut occurs.

Based on the description above, the writer is interested in raising a title, namely "Designing Android-based Core Fiber Optic Management Information System at PT.Telkom Kebumen". The author intends to create an Android-based application design that is useful to help facilitate the work of employees, especially repair or assurance technicians at PT. Telkom Kebumen. The choice of using Android because all technicians at PT. Telkom Kebumen are required to use an Android smartphone, also Android applications are easier to access by all smartphone brands .

\section{Research Methodology}

The method used in data collection is descriptive method. The data collection techniques are carried out as follows:

a) Observation Method

In this case the authors collect data directly by observing and recording also various other things needed in the research process, this activity is carried out to find out what problems exist in the optical fiber core management system of PT. Telkom Kebumen.

b) Interview Method

The author conducted interviews with field technicians who manage fiber optic core (mancore) management to find out data and information on problems in terms of managing fiber optic mancore at PT. Telkom is faced today.

c) Literature Study

Collecting data and information by utilizing reference books from the internet and various discourses related to core fiber optic management information systems relating to core fiber optic management information systems that can be used as a reference in the completion of this report.

d) Documentation Method

In this case the agency provides reference data as a reference for making the Core Fiber Optic Management Information System at PT. Telkom Kebumen.

\section{Results and Discussion}

\subsection{Problem Analysis}

Based on the analysis of the system currently running at PT. TELKOM Kebumen for core management processing systems, has not used an efficient and effective system. Therefore, the authors propose to create an Android-based Core Fiber Optic Management Information System so that technicians are facilitated to repair Fiber Optic cables and reduce errors due to Core Management data that is not updated and inaccurate. 


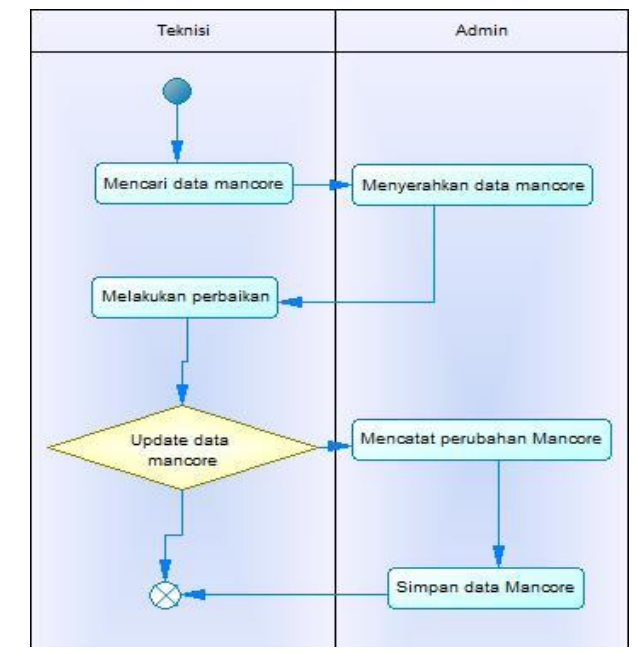

Figure 1. Activity diagram that runs

\subsection{Proposed System Design}

a) Use Case Diagram

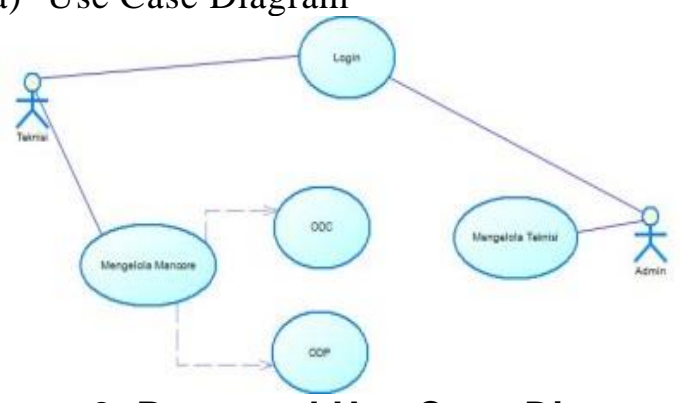

Figure 2. Proposed Use Case Diagram b) Use Case Diagram

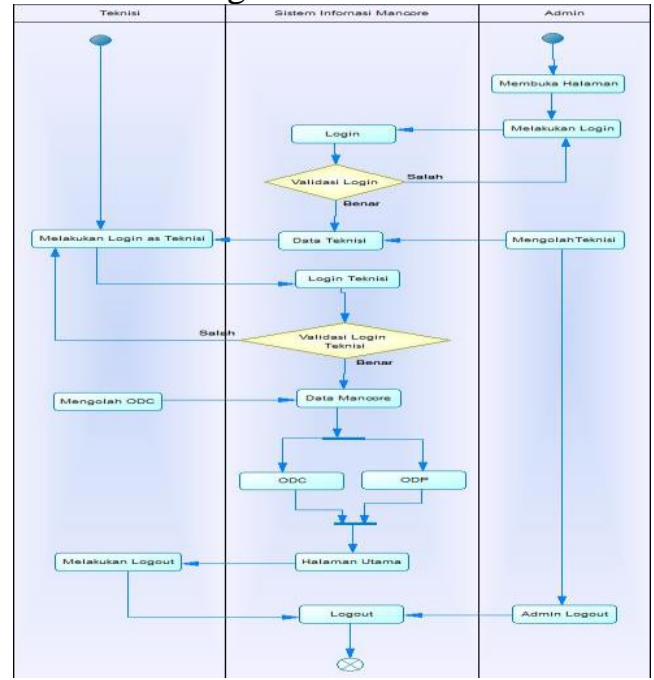

Figure 3. Proposed Activity Diagram

d) Statechart Diagram

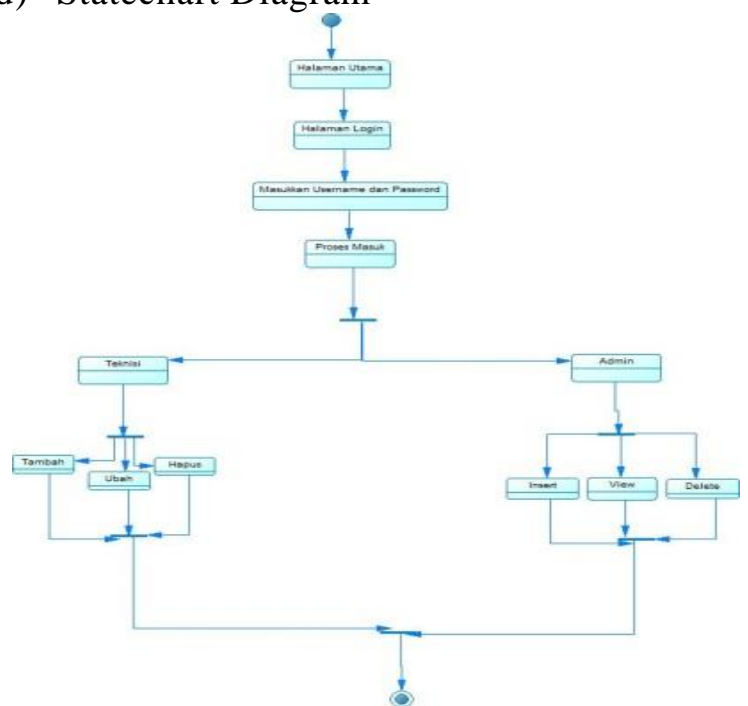

Figure 5. Proposed Statechart Diagram
Figure 4. Proposed Class Diagram

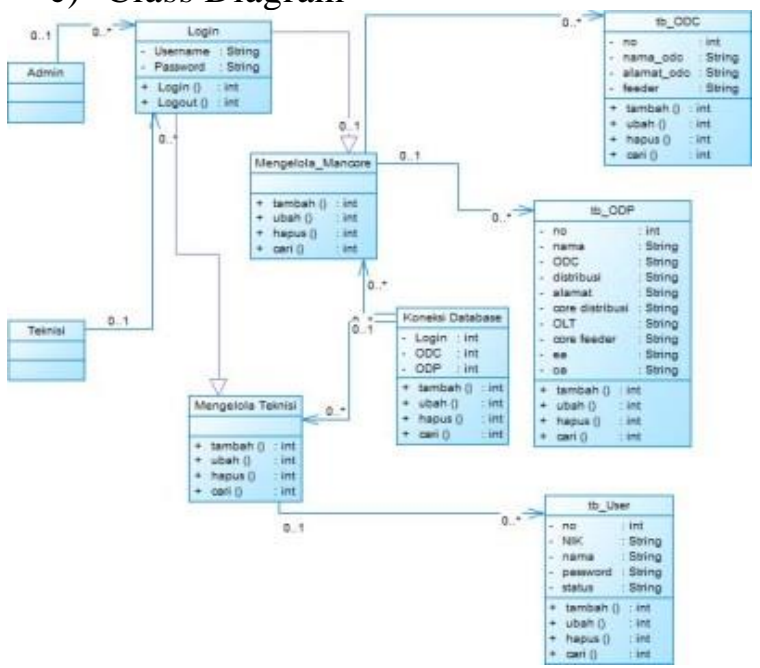


3.3. System Interface Implementation

a) Login Page

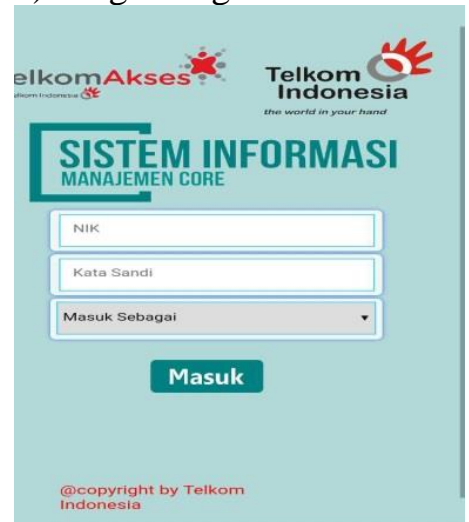

Figure 6. Login Page Display

c) Admin Menu

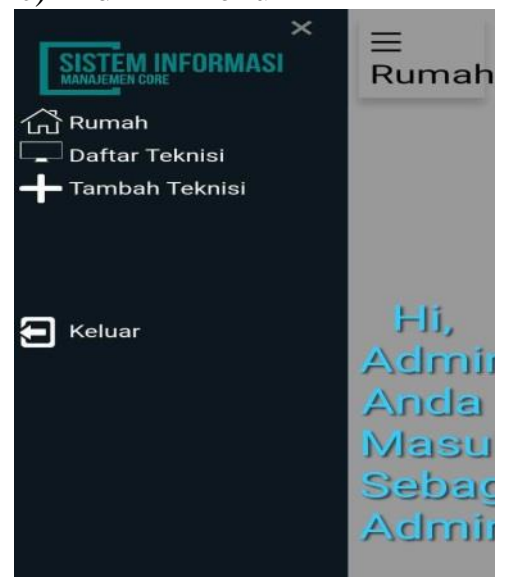

Figure 8. Display Admin Menu

e) Add User Page

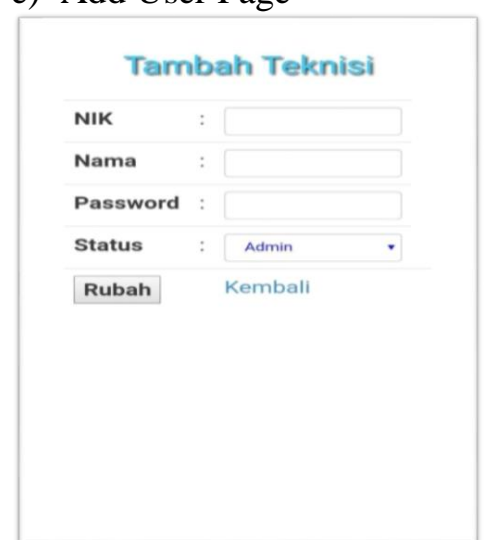

Figure 10. Display Page Add User b) Admin Main Page

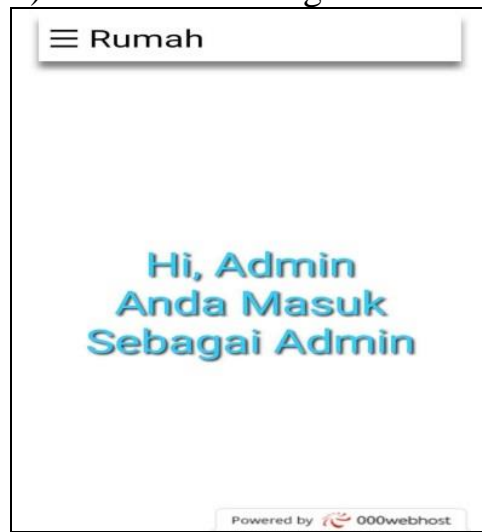

Figure 7. Display Admin Main Page

d) Register / Search User page

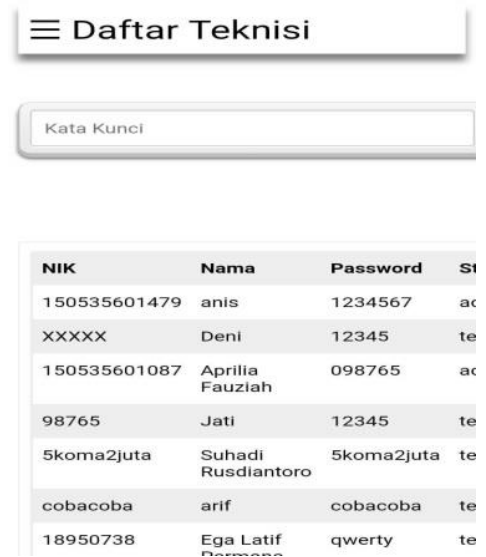

Figure 9. Display List Page / Search User

f) Technician Main Page

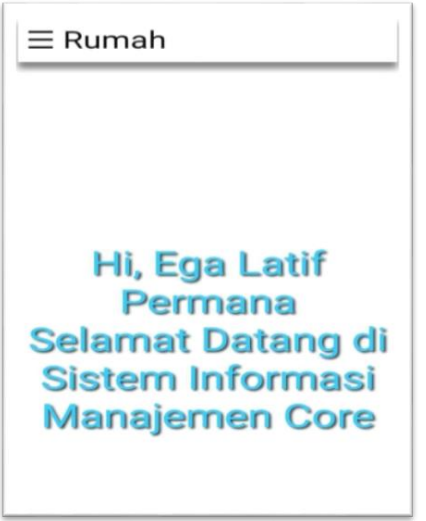

Figure 11. Display Main Page Technician 
g) Technician Menu

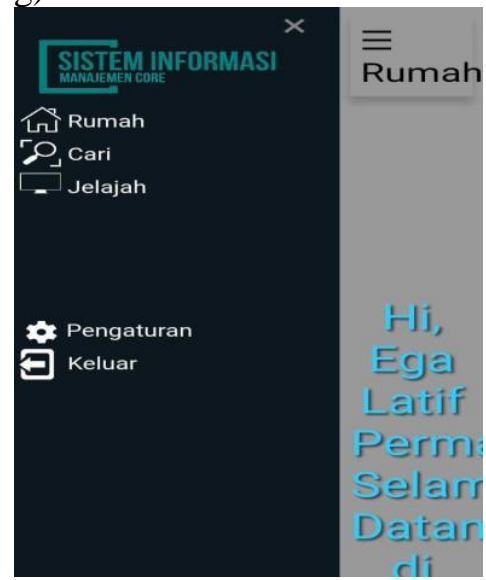

Figure 12. Technician Menu Display

i) ODC List Page

E Explore

Silahkan Jelajahi Sistem Management Core yang Anda Perlukan

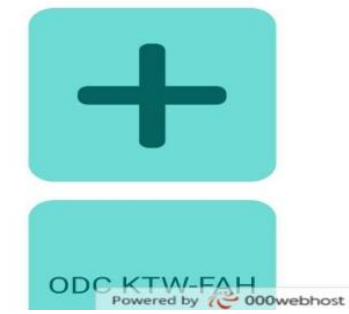

Figure 14. Display of the ODC List Page h) Register / Search ODP page

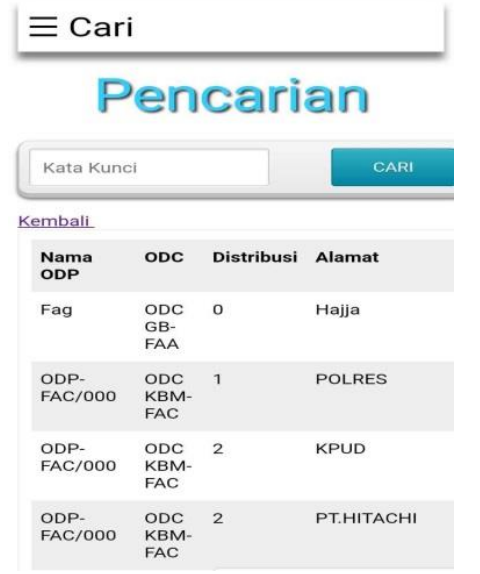

Figure 13. Display Main Page

j) ODC and ODP Details Page

$\equiv$ ODC KTW-FAH

Jumlah Distribusi : 4
Alamat: UNGARAN
Fedeer : $1-12$

Kembali

+ Tambah ODP Baru

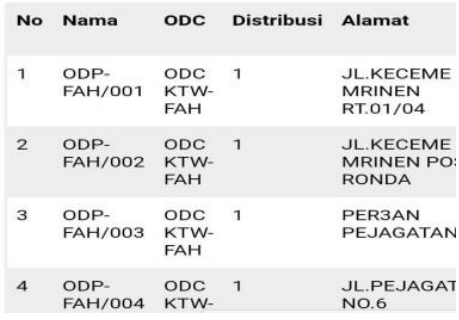

Figure 15. Display of ODC and ODP Details Pages

\section{Conclusion}

The author concludes what has been explained namely as follows:

a) The fiber optic core management system at PT.Telkom Kebumen is currently using a conventional system in the form of data stored in a file with Ms.Excel extension. So the addition of data or data changes are still slow and the data and information provided is not accurate.

b) The problem that often occurs in the system used today is that many stored data are inaccurate with the conditions in the field so that it slows down / inhibits when troubleshooting fiber optic networks.

c) To build an Android-based Core Fiber Optic Management Information System at PT. Telkom Kebumen requires scripting coding programming languages html, phph, and css. To build its database requires MySql and requires hosting so that it can be accessed online. The last is a web to apk converter needed to convert a dynamic web into an android application so that it can be installed on the smartphone of PT.Telkom Kebumen technician. 
With the completion of this research writing, the writer wants to provide suggestions for the progress of the company, including:

a) Data backups need to be done so that when the application error / lost there is still data backup.

b) Need to do maintenance and maintenance of software.

c) Socialization needs to be done before implementing a new mancore system.

d) Update hosting to premium vresi so that hosting capacity is more adequate if, so it can hold more data.

\section{References}

[1] Arief, R. M. (2011). Program WEB Dinamis Menggunakan PHP dan MySQL. Penerbit ANDI: Yogyakarta

[2] Dharwiyanti, Sri dan Wahono, Romi (2003). Pengantar Unified Modelling Language (UML). IlmuKomputer.com.

[3] Jogiyanto. (2005). Analisis dan Desain Sistem Informasi. Penerbit ANDI: Yogyakarta.

[4] Kadir, Abdul. (2005). Dasar Pemrograman WEB Dinamis Menggunakan PHP. Andi Offset: Yogyakarta..

[5] Kadir, Abdul. (2018). Pemrograman Android \& Database. Elex Media Komputindo: Yogyakarta.

[6] Ladjamudin, Al. Bahra. (2005). Analisis dan Desain Sistem Informasi. Graha Ilmu: Yogyakarta.

[7] Marlina, Linda, S. Kom. (2010). Sistem Basis Data. Andi Offset: Yogyakarta.

[8] Nugroho, Bunafit. (2004). PHP dan MySQL dengan Dreamweaver MX. Penerbit ANDI: Yogyakarta.

[9] Peranginangin, K. (2006). Aplikasi WEB dengan PHP dan MySQL. Andi Offset: Yogyakarta.

[10] Wahana Komputer . (2006). Seri Panduan Lengkap Menguasai Pemrograman WEB dengan PHP 5 . Andi Offset dan Wahana Komputer: Semarang.

\section{Authors}

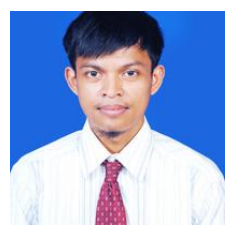

$1^{\text {st }}$ Author

Ari Waluyo

Electronic Engineering Study Program, Politeknik Dharma Patria Kebumen 